\title{
Contribution to chromosome numbers and phylogeny of Turkish Vincetoxicum Wolf (Apocynaceae, Asclepiadoideae)
}

\author{
Seher GÜVEN ${ }^{1, *}$, Serdar MAKBUL ${ }^{2}$ \& Kamil COŞKUNÇELEBİ ${ }^{3}$ \\ ${ }^{1,2}$ Recep Tayyip Erdogan University, Faculty of Sciences and Arts, Department of Biology, \\ 53100, Rize, Turkey. \\ ${ }^{3}$ Karadeniz Technical University, Science Faculty, Department of Biology, \\ 61080 Trabzon, Turkey. \\ *Corresponding author: cakmakseher@hotmail.com \\ 2Email:smakbul@hotmail.com \\ ${ }^{3}$ Email: kamil@ktu.edu.tr
}

\begin{abstract}
We report chromosome counts for ten taxa of Vincetoxicum sensu stricto (s. str.) (Apocynaceae) from Turkey (of which two are endemic), including the first chromosome counts for $V$. canescens subsp. pedunculata, V.funebre, V. fuscatum subsp. boissieri, V. parviflorum and V. tmoleum. Two taxa of V. fuscatum proved to be tetraploid $(2 n=44)$ and the remaining eight taxa diploid $(2 n=22)$. Molecular phylogenetic analyses based on nrDNA (ITS) and cpDNA (trnT-trnL) (including 31 newly generated sequences) confirm the position of the Turkish Vincetoxicum in the Vincetoxicum s. str. clade. Vincetoxicum fuscatum, V. parviflorum, V. speciosum, as well as the Turkish endemic V. fuscatum subsp. boissieri, were clearly resolved as species-level clades, whereas the delimitation of the rest of the Turkish taxa was less clear based on molecular data.
\end{abstract}

Keywords. Cytology, molecular phylogeny, Turkey, Vincetoxicum.

Güven S., Makbul S. \& Coşkunçelebi K. 2019. Contribution to chromosome numbers and phylogeny of Turkish Vincetoxicum Wolf (Apocynaceae, Asclepiadoideae). European Journal of Taxonomy 590: 1-19. https://doi.org/10.5852/ejt.2019.590

\section{Introduction}

Vincetoxicum Wolf is one of the largest and most widespread genera of the subfamily Asclepiadoideae (Apocynaceae). Molecular data indicated that Vincetoxicum sensu lato (s. lat.), comprising ca 150 species, is widely distributed from Australasia and the Far East to Africa, Europe, and North America (Liede-Schumann et al. 2016). The well-defined Vincetoxicum s. str. clade with ca 45 species extends from the Far East via the Asian mountain ranges into Central Europe and was also introduced in North America (Liede-Schumann et al. 2016). Vincetoxicum displays the flowers typical of the subfamily with gynostegium and five pollinaria, its sterile corona is staminal and characteristically composed of five fleshy lobes separated near the base or partly connected by smaller interstaminal parts (Liede 1996). In addition, most Vincetoxicum individuals have been determined to be poisonous to humans, and some 
have been used in conventional and folk medicine as well as in modern medicine (Zaidi \& Crow 2005; Mansoor et al. 2011).

Vincetoxicum was considered to be a systematically difficult genus due to the complex floral features which could be variable even at the species level (Browicz 1978). The genus contains many morphologically close taxa, and there have long been various interpretations over the taxonomic distinction of Vincetoxicum from its closely related genera in the same tribe (Asclepiadeae); Cynanchum L. (subtribe Cynanchinae K.Schum.) and Tylophora R.Br. (subtribe Tylophorinae), which are known by their similar corona, gynostegium and pollinarium structures (Liede-Schumann et al. 2012). Vincetoxicum was recognized as a separate genus from Cynanchum by some taxonomists (Pobedimova 1952; Grossheim 1967; Rechinger 1970; Markgraf 1972; Browicz 1978; Ali 1983), while others preferred to classify it under Cynanchum at the rank of subgenus (Domin 1928) or section (Tsiang \& Li 1977; Forster 1991). Some morphological (Liede 1996; DiTommaso et al. 2005; Yamashiro et al. 2008), palynological (Chang et al. 2012; Feng et al. 2012; Shah \& Ahmad 2014; Yaseen \& Perveen 2014), chemical (Stærk et al. 2002; Zaidi \& Crow 2005, 2012; Mansoor et al. 2011), cytological (Liede-Schumann et al. 2012) and molecular (Sennblad 1997; Civeyrel et al. 1998; Liede 2001; Liede et al. 2002; Yamashiro et al. 2004; Liede-Schumann et al. 2012, 2016) studies, including a few taxa of Vincetoxicum, have been carried out on Asclepiadoideae in order to contribute to the taxonomy of the subfamily. Recently, LiedeSchumann et al. $(2012,2016)$, based on molecular data (nrDNA and cpDNA markers), indicated that in the subtribe Tylophorinae, containing Biondia Schltr., Blyttia Arn., Diplostigma K.Schum., Goydera Liede, Pentatropis R.Br., Pleurostelma Baill., Rhyncharrhena F.Muell., Tylophora and Vincetoxicum, all genera, except Pentatropis, are non-monophyletic. Therefore, the researchers suggested to merge the remaining eight genera of the subtribe Tylophorinae into a single genus, Vincetoxicum s. lat. (LiedeSchumann et al. 2012, 2016). Consequently, Liede-Schumann \& Meve (2018) formally transferred the members of these genera to Vincetoxicum s. lat., the oldest established genus name.

Browicz (1978), who recognised six species and four subspecies, excluding doubtful records, presented a comprehensive treatment of Vincetoxicum s. str. in Turkey. Since then, Güner (2012) listed ten taxa of Vincetoxicum s. str. from Turkey, including endemics (V. fuscatum Rchb. subsp. boissieri (Kusn.) Browicz and V. parviflorum Decne.). Vincetoxicum s. str. grows in various habitats ranging from dry river valleys, open rocky slopes, steppes and mountain slopes, to shrubland and Quercus-dominated forests in Turkey (Browicz 1978). Until now, a few anatomical and seed micro-morphological (Ilçim et al. 2010), ethnobotanical (Doğan 2008; Altundağ \& Öztürk 2011), pharmaceutical (Özay 2013), and palynological (Güven et al. 2015) studies have been reported on Turkish Vincetoxicum s. str. taxa.

Chromosome number data remain valuable today in systematics, and establishing which plants are polyploids and which are diploids is important to allow for a better understanding of plants to be included in phylogenetic studies. Polyploidy, widely accepted as a mechanism of reproductive isolation and plant speciation, has been an important force shaping the evolutionary history of vascular plants. It is estimated that between $15 \%$ and $30 \%$ of speciation in angiosperms results from polyploidy. Over the last decade, there has been an increase in studies investigating how polyploids influence phylogenetic community structure by combining ploidal information with phylogenetic analyses of plant communities. The polyploid and diploid species have been identified as having phenotypic differences and molecular variations associated with whole genome duplication. While these differences are considered to increase the ecological success of polyploids in novel communities, it remains relatively unexplored whether polyploids are indeed better competitors in a community context (Gregg et al. 2017; Gaynor et al. 2018). For nearly a century, botanists in particular, have been interested in the determination and documentation of chromosome numbers which have been extensively utilized as an important phylogenetic character in the context of cytotaxonomy (Rice et al. 2015). Although these data have been documented along the years, to date, chromosome number data of only approximately $25 \%$ of flowering plants have been 
determined (Stace 2000; Garbari et al. 2012). Despite the great floristic richness of Turkey, only 15\% of the vascular plant taxa have had their chromosome number investigated (Vladimirov et al. 2015).

The aim of the present study was: 1) to report the chromosome number of Turkish representatives of Vincetoxicum s. str. since very few counts have been reported in the literature previously; and 2) to contribute to the phylogenetic position of Vincetoxicum s. str. (of which two are endemic) based on newly generated sequences from Turkish accessions.

\section{Material and methods}

\section{Sampling}

Locality information of samples used for chromosome counting and molecular studies is presented in Appendix 1. Of these, 16 representatives belonging to 10 Turkish taxa of Vincetoxicum s. str. were used in somatic chromosomal studies. In total, 59 accessions (Vincetoxicum s. str. (53), Cionura erecta L. (3), Cynanchum acutum L. (2) and Gomphocarpus fruticosus (L.) W.T.Aiton (1)) were used for molecular analysis (Appendix 1). Of these, one Cynanchum, three Cionura and 31 Vincetoxicum s. str. members were collected by the present authors from their natural habitats in Turkey (Appendix 1). All specimens were first processed using the standard herbarium techniques given by Woodland (1997); they were identified using the Flora of Turkey (Browicz 1978), Flora of Russia (Pobedimova 1952), Flora Europaea (Markgraf 1972), and stored at the Herbarium of Recep Tayyip Erdogan University, Department of Biology (RUB).

\section{Cytological analyses}

For somatic chromosomal examination, the mature seeds were germinated on wet filter paper in Petri dishes at $+27^{\circ} \mathrm{C}$. Active roots were cut at $1-1.5 \mathrm{~cm}$ from the tips and these were pretreated for 16 hours in $\alpha$-monobromonaphthalene at $+4^{\circ} \mathrm{C}$ and then fixed using Carnoy solution $(3: 1$ absolute alcohol:glacial acetic acid) overnight. Fixed root tips were transferred to $70 \%$ alcohol and stored at $+4^{\circ} \mathrm{C}$ until analysis. Afterwards, the root tips were hydrolyzed with $1 \mathrm{~N} \mathrm{HCl}$ for 12 minutes at $60^{\circ} \mathrm{C}$ and stained with $2 \%$ aceto orcein for 24 hours at room temperature. Stained root tips were squashed in a drop of $45 \%$ acetic acid and the preparations were mounted in entellan in order to obtain permanent slides. The best metaphase plates, including at least ten well-spread cells, were photographed with an Olympus BX51 microscope with an attached digital camera, and they were also drawn from permanent slides. For chromosome counting, both the $10 \times 100$ enlarged photographs and the drawings were used (Jones \& Rickards 1991; Elçi 1994; Martin et al. 2019).

\section{DNA isolation, PCR amplification, and sequencing}

Total genomic DNA was extracted from silica dried leaves following the modified CTAB extraction procedure of Doyle \& Doyle (1987). The nrITS region and $\operatorname{trn}$ T-trnL spacer were amplified using the universal 'ITS4 and ITS5' primers (White et al. 1990) and the universal 'a and b' primers (Taberlet et al. 1991), respectively, according to the PCR conditions described by Gültepe et al. (2010). The PCR products were sequenced with the aid of Macrogen Inc. (Seoul, Korea) using the same primers.

\section{DNA sequence alignment and phylogenetic analyses}

The nucleotide sequences were aligned by ClustalW using BioEdit v.7.0 software (Hall 1999). The obtained sequence data were compared with GenBank sequences using BLAST and manually verified. For both ITS and trnT-trnL sequences, total nucleotide length (bp), parsimony informative sites and the interspecific and intraspecific pairwise differences from a distance matrix were calculated using MEGA v.7.0 (Kumar et al. 2016). 
The phylogenetic analysis included 52 Vincetoxicum taxa attributed to the 'Vincetoxicum s. str. clade', as well as one accession attributed to the 'Far Eastern clade' according to Liede-Schumann et al. (2016). Of these, 31 accessions belonged to 10 taxa of Turkish Vincetoxicum s. str. (Appendix 1), and the dataset of ITS and $\operatorname{trn} \mathrm{T}-\operatorname{trn} \mathrm{L}$ belonging to the remaining 22 accessions studied by Liede-Schumann et al. (2016) was retrieved from GenBank (www.ncbi.nlm.nih.gov). Our sampling aimed to cover the area of the genus Vincetoxicum s. str. in Turkey as completely as possible, with particular emphasis on the 'Vincetoxicum s. str. clade' including the taxa attributed to the European, Western Irano-Turanian, Eastern Mediterranean, Southern Russian, Eastern Irano-Turanian, and Western Himalayan clades (Liede-Schumann et al. 2016), which are neighbouring regions to Turkey. As outgroup, six specimens belonging to three different species of Asclepiadoideae (Cionura erecta, Cynanchum acutum and Gomphocarpus fruticosus), which are also distributed in Turkey, were selected for the phylogenetic analysis (Appendix 1).

The two dataset (ITS and $\operatorname{trn}$ T-trnL) were combined according to the ILD test results of Liede-Schumann et al. (2012). Phylogenetic relationships were reconstructed using Bayesian Inference (BI) analyses and Maximum Parsimony (MP). For Bayesian Inference (BI) analyses, evolutionary models were assessed with Akaike information criterion (AIC) as implemented in MrModeltest 2.3 software (Nylander 2004). The most suitable models, as detected by AIC, were GTR $+\mathrm{G}$ for the nrDNA ITS marker and GTR $+\mathrm{I}$ for the cpDNA trn T-trnL marker. The BI methods were carried out using MrBayes ver. 3.1 (Ronquist \& Huelsenbeck 2003). For the BI analyses, a Metropolis-coupled Markov chain Monte Carlo (MCMCMC) algorithm was employed with two simultaneous runs of four parallel MCMCMC each for 1 million generations, starting with a random tree. The trees were saved every $1000^{\text {th }}$ generation, and the first $20 \%$ were discarded as 'burn-in'. The remaining trees were used to estimate the majority rule consensus tree and Bayesian posterior probabilities (PP).

Maximum Parsimony (MP) methods were implemented in the PAUP* ver. $4.0 \mathrm{~b} 10$ (Swofford 2003) software. For the MP analyses, a script was first created using the parsimony ratchet (Nixon 1999) method implemented in the PRAP v.2.0 (Müller 2004). The script contains standard ratchet settings (200 ratchet iterations with $25 \%$ of the positions randomly upweighted (weight $=2$ ) during each replicate and 10 random additional cycles). This file, containing the sequence data and commands, was analysed by Jackknife (JK) in PAUP* ver. 4.0b10 (Swofford 2003) to calculate JK support values for the branches. Then, MP analysis in PAUP* ver. 4.0b10 (Swofford 2003) was performed with 1000 repetitions according to the majority rule. The JK support values were transferred to the phylogenetic tree obtained from the results of the MP analysis. Indels were coded as informative characters according to the Simple Indel Coding (SIC) method (Simmons \& Ochoterena 2000) as implemented in the programme SeqState ver. 1.40 (Müller 2005) and added at the end of the sequence dataset.

In phylogenetic analyses based on sequence data, monophyly, branch lengths, branch support and genealogical concordance have been reported as often-used criteria for species delimitation (Leliaert et al. 2014). Our phylogeny based on nrDNA (ITS) and cpDNA (trnT-trnL) sequences contains multiple specimens per species, and species are delimited based on topological criteria, monophyly and branch support. Additionally, some typical floral characteristics of Vincetoxicum s. str., which were not analysed, were also presented in our phylogenetic tree in order to see whether there is a concordance between molecular data and these diagnostic characteristics.

\section{Results}

\section{Chromosome numbers}

Chromosome counts for 16 accessions belonging to ten taxa of Vincetoxicum s. str. from Turkey are presented in Figs 1-2. The somatic chromosome numbers were determined as $2 n=4 x=44$ in two subspecies 


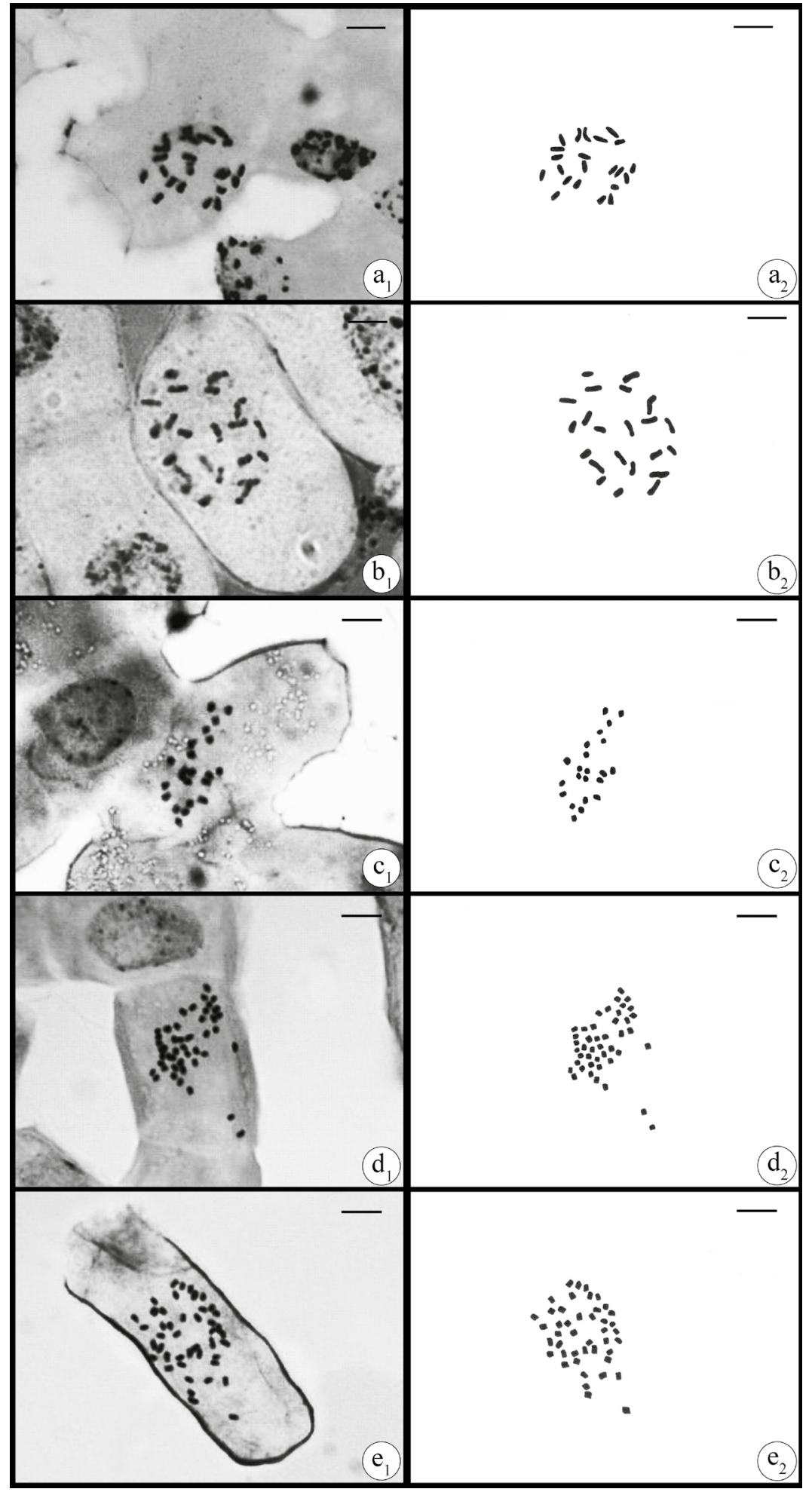

Fig. 1. Somatic metaphase chromosome $(1=$ light microscope; $2=$ outline drawing $)$ a. Vincetoxium canescens (Willd.) Decne. subsp. canescens (Güven $36 \&$ Makbul, $2 n=22)$. b. V. canescens (Willd.) Decne. subsp. pedunculata Browicz (Güven $51 \&$ Makbul, $2 n=22$ ). c. V. funebre Boiss. \& Kotschy (Güven $126 \&$ Makbul, 2n=22). d. V. fuscatum (Hornem.) Rchb. subsp. boissieri (Kusn.) Browicz (Güven 35 \& Makbul, 2n=44). e. V. fuscatum (Hornem.) Rchb. subsp. fuscatum (Güven 93 \& Makbul, $2 n=44)$. Scale bars $=5 \mu \mathrm{m}$. 


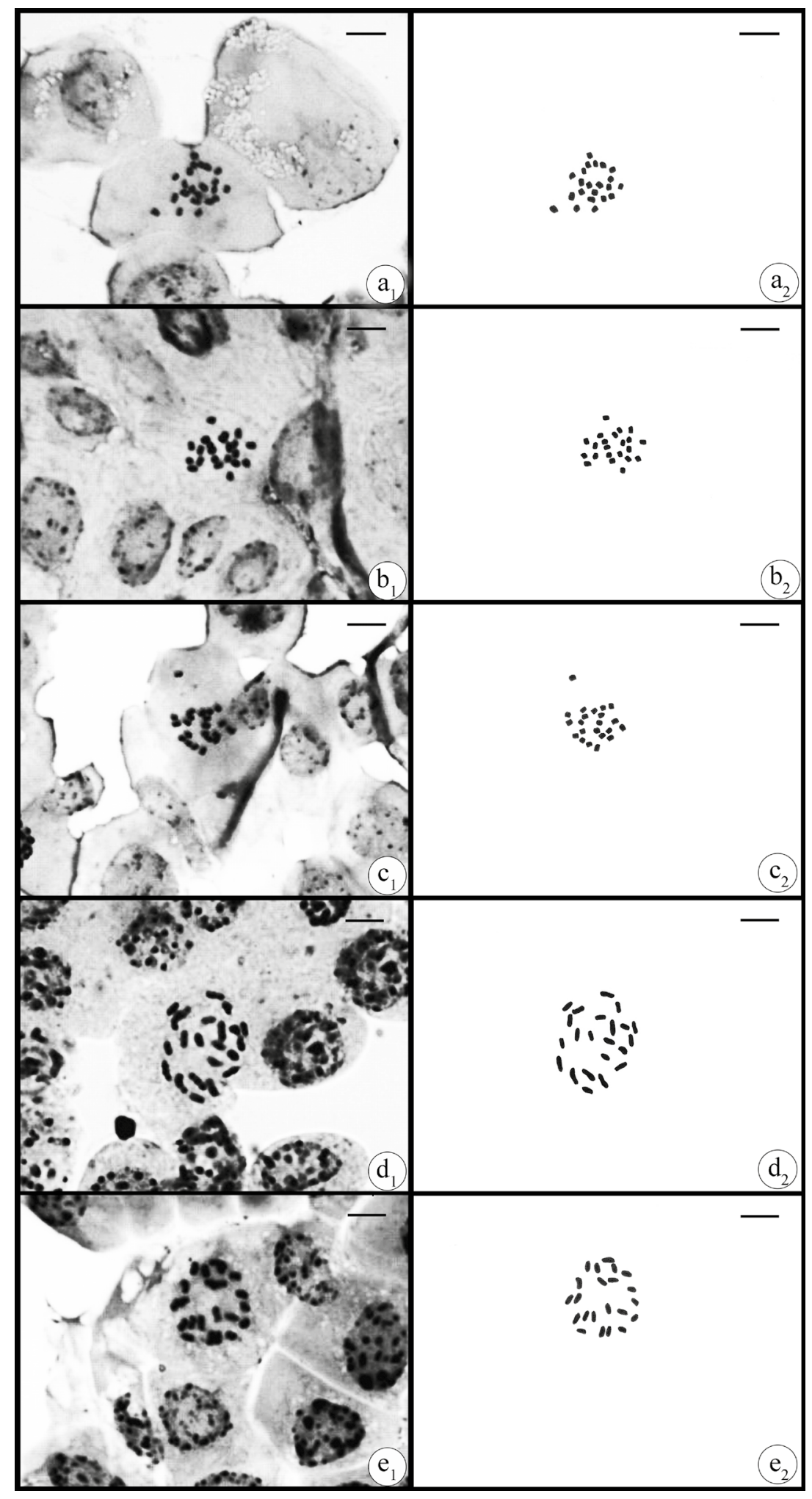

Fig. 2. Somatic metaphase chromosome $(1=$ light microscope; $2=$ outline drawing $)$. a. Vincetoxicum hirundinaria Medik. subsp. hirundinaria (Güven $135 \&$ Makbul, $2 n=22$ ). b. V. parviflorum Decne. (Güven 80 \& Makbul, 2n=22). c. V. scandens Sommier \& Levier (Güven 30 \& Makbul, 2n=22). d. . speciosum Boiss. \& Spruner (Güven $137 \&$ Makbul, $2 n=22$ ). e. V. tmoleum Boiss. (Güven 72 \& Makbul, $2 n=22$ ). Scale bars $=5 \mu \mathrm{m}$. 
Table 1. List of specimens used for cytological studies.

\begin{tabular}{|c|c|c|c|c|}
\hline Taxa & Vouchers & $\begin{array}{l}\text { IUCN cate- } \\
\text { gories (Ekim } \\
\text { et al. 2000) }\end{array}$ & $\begin{array}{l}\text { Present } \\
\text { chromosome } \\
\text { counts }\end{array}$ & $\begin{array}{l}\text { Previous } \\
\text { records }\end{array}$ \\
\hline $\begin{array}{l}\text { V. canescens } \\
\text { subsp. canescens }\end{array}$ & Güven 36 \& Makbul & - & $2 n=2 x=22$ & $2 n=2 x=22(\mathrm{Li}$ et al. 1995$)$ \\
\hline $\begin{array}{l}\text { V. canescens } \\
\text { subsp. pedunculata }\end{array}$ & Güven $51 \&$ Makbul & VU & $2 n=2 x=22$ & - \\
\hline V.funebre & Güven $126 \&$ Makbul & $\mathrm{DD}$ & $2 n=2 x=22$ & - \\
\hline $\begin{array}{l}\text { V. fuscatum } \\
\text { subsp. boissieri }\end{array}$ & $\begin{array}{l}\text { Güven } 32 \text { \& Makbul, } \\
\text { Güven } 35 \text { \& Makbul }\end{array}$ & LC (endemic) & $2 n=4 x=44$ & - \\
\hline $\begin{array}{l}\text { V. fuscatum } \\
\text { subsp. fuscatum }\end{array}$ & $\begin{array}{l}\text { Güven } 23 \text { \& Makbul, } \\
\text { Güven } 77 \text { \& Makbul, } \\
\text { Güven } 93 \text { \& Makbul }\end{array}$ & - & $2 n=4 x=44$ & $\begin{array}{l}2 n=2 x=22(\text { Strid } \& \\
\text { Franzen } 1981)\end{array}$ \\
\hline $\begin{array}{l}\text { V. hirundinaria } \\
\text { subsp. hirundinaria }\end{array}$ & $\begin{array}{l}\text { Güven } 18 \& \text { Makbul, } \\
\text { Güven } 28 \& \text { Makbul, } \\
\text { Güven } 135 \& \text { Makbul }\end{array}$ & - & $2 n=2 x=22$ & $\begin{array}{l}2 n=2 x=22 \text { (Uhríková et al. } \\
\text { 1985; Liede-Schumann et } \\
\text { al. 2012) }\end{array}$ \\
\hline V. parviflorum & Güven 80 \& Makbul & NT (endemic) & $2 n=2 x=22$ & - \\
\hline V. scandens & Güven 30 \& Makbul & - & $2 n=2 x=22$ & $\begin{array}{l}2 n=2 x=22(\text { Lessani \& } \\
\text { Chariat-Panahi 1979) }\end{array}$ \\
\hline V. speciosum & Güven $137 \&$ Makbul & & $2 n=2 x=22$ & $2 n=2 x=22($ Pardi 1933) \\
\hline V.tmoleum & $\begin{array}{l}\text { Güven } 67 \text { \& Makbul, } \\
\text { Güven } 72 \& \text { Makbul }\end{array}$ & - & $2 n=2 x=22$ & - \\
\hline
\end{tabular}

of $V$. fuscatum (subsp. fuscatum and subsp. boissieri) and $2 n=2 x=22$ in the rest of the examined taxa. To the best of our knowledge, these are the first chromosome counts for $V$. canescens subsp. pedunculata, V. funebre, V. fuscatum subsp. boissieri, V. parviflorum and V. tmolem (Table 1).

\section{DNA sequence alignments}

For the 31 examined Turkish Vincetoxicum s. str. samples, the length of the amplified nrDNA ITS region was 617 or $618 \mathrm{bp}$. The gap-less alignment of $618 \mathrm{bp}$, included 594 (96.1\%) constant, 24 (3.9\%) variable and $23(3.7 \%)$ parsimony informative sites. The estimated Transition/Transversion bias (R) was 3.69. The length of the $\operatorname{trn} \mathrm{T}-\operatorname{trn} \mathrm{L}$ region was $804 \mathrm{bp}$. The dataset had an aligned length of 804 sites, of which $802(99.8 \%)$ were constant, $2(0.25 \%)$ were variable and 1 was $(0.12 \%)$ parsimony informative. $\mathrm{R}$ was determined as 0.00 .

\section{Phylogenetic analyses}

The topologies of the phylogenetic trees inferred from the concatenated alignment of nrDNA ITS + trnT$\operatorname{trn} \mathrm{L}$ using MP and BI analyses were similar. Therefore, the Bayesian majority rule tree is shown in Fig. 3 , along with JK support values of the MP analysis. The phylogenetic tree revealed that all the examined taxa of Vincetoxicum were separated from the outgroup (which included specimens belonging to the three separate species: Cionura erecta, Cynanchum acutum and Gomphocarpus fruticosus) and formed a clade composed of two subclades, I and II. Clade I comprised only V. atratum corresponding to the 'Far Eastern clade' in Liede-Schumann et al. (2016), and clade II, corresponding to the 'Vincetoxicum s. str. clade' in Liede-Schumann et al. (2016), included all the remaining ingroup taxa. Our phylogenetic tree (Fig. 3) revealed that among the examined taxa of Turkish Vincetoxicum s. str., only V. fuscatum, 
$V$. parviflorum and $V$. speciosum were recovered as monophyletic, whereas the delimitation of the remaining six taxa was less clear based on molecular data. In the phylogenetic tree, some typical floral characteristics of the investigated taxa of Vincetoxicum s. str. such as the indumentum of the corolla and shape of the corona (which were not analysed) were also presented. Nevertheless, these characters seemed to be homoplastic, since they appeared in different subclades.

\section{Discussion}

In the present study, the chromosome number for ten taxa of Vincetoxicum s. str. from Turkey, including two endemics, are reported. In addition, the phylogenetic positions of $V$. fuscatum subsp. boissieri and $V$. parviflorum, which are endemic to Turkey, were investigated based on nrDNA ITS and cpDNA $\operatorname{trn} \mathrm{T}-\operatorname{trn} \mathrm{L}$ with 31 newly generated sequences.

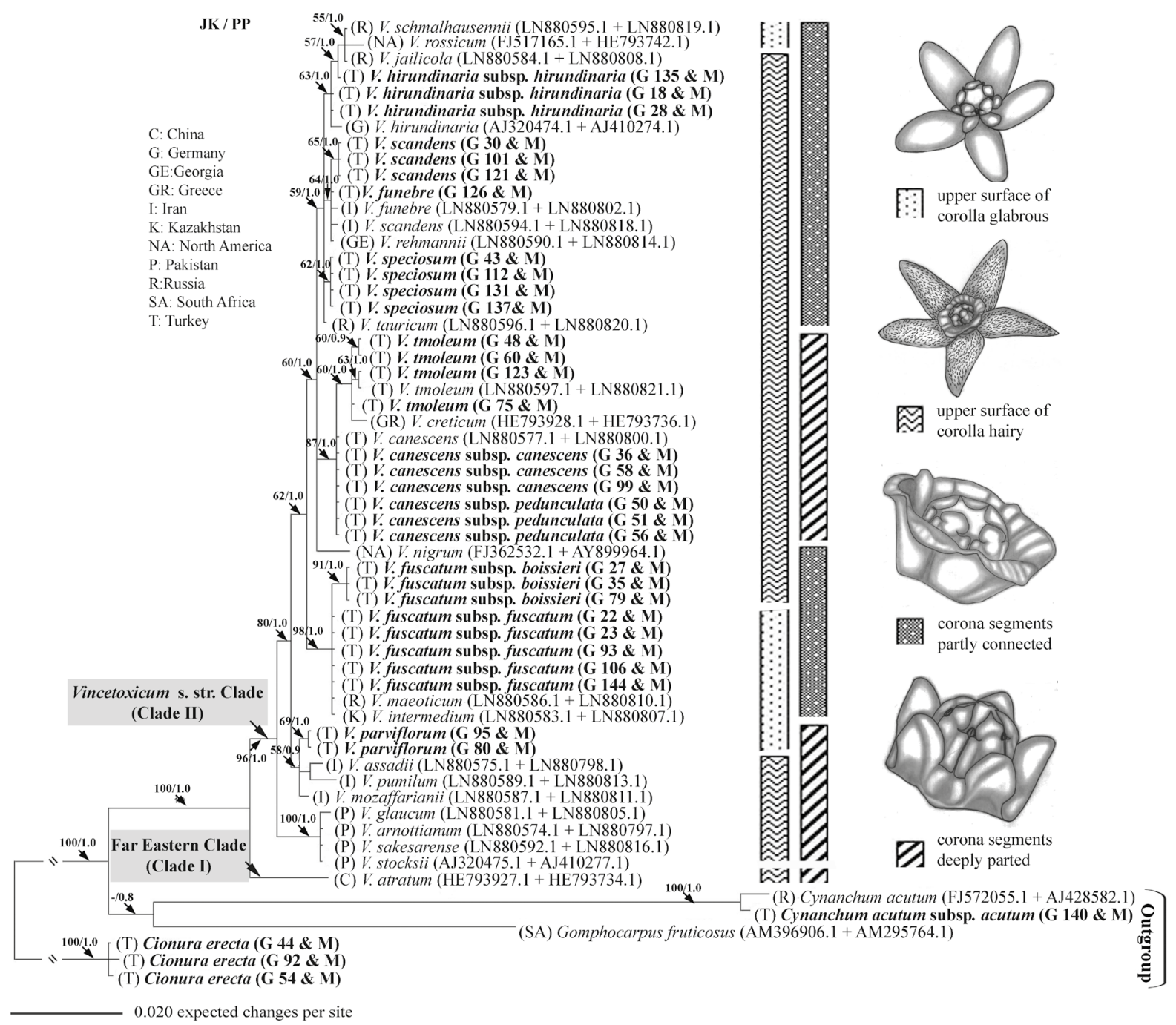

Fig. 3. Phylogenetic tree of Vincetoxicum s. str., including Turkish samples (in bold) based on the combined dataset (ITS and $\operatorname{trn} \mathrm{T}-\mathrm{trn} \mathrm{L}$ ). The support values on branches indicate Jackknife (JK) and Posterior Probability (PP) higher than 50\% and 0.7, respectively. Clade designations correspond to Liede-Schumann et al. (2016). Refer to Appendix 1 for accession abbreviations (G:Güven, M:Makbul). 
In the Flora of Turkey (Browicz 1975), the yellow flowered V. canescens was represented by two subspecies, subsp. canescens and subsp. pedunculata, which were shown in the present study to be diploid according to two Turkish accessions. The chromosome number of the other yellowish flowered Turkish Vincetoxicum s. str., V. tmoleum, was determined as $2 n=2 x=22$ from two Turkish accessions. To the best of our knowledge, these are the first chromosome counts for $V$. canescens subsp. pedunculata and $V$. tmoleum. Similarly, $V$. canescens subsp. canescens has previously been reported as diploid $(2 n=2 x=22)$ in the Flora of China ( $\mathrm{Li}$ et al. 1995). Our chromosomal data on $V$. canescens subsp. canescens originating from Turkey is in accordance with these previous results.

According to our phylogenetic analyses, $V$. canescens and $V$. tmoleum also clustered in the same group (including V. creticum) corresponding to the 'Eastern Mediterranean clade' in Liede-Schumann et al. (2016). It was reported that these two species had many morphological and palynological characteristics in common, such as densely hairy corolla and deeply parted corona segments (Güven 2017), an ovate pollinium and corpusculum shape, and a rugulate pollen surface (Güven et al. 2015). The similarity in floral morphology between $V$. canescens and V. tmoleum was also reported by Browicz (1975). In addition, the same chromosome number was determined for $V$. canescens and $V$. tmoleum. However, the stem and fruit morphology of the two species are quite different. Vincetoxicum canescens, characterised by decumbent stems with a canescent-tomentose indumentum and ovoid fruits, is easily distinguished from V.tmoleum, which has erect and crisped hairy stems and slender ovoid fruits (Browicz 1975; Güven 2017). Vincetoxicum creticum (endemic to Crete-Greece) clustered with $V$. tmoleum in the same sub-clade. This species was previously reported as morphologically close to V. tmoleum by Browicz (1975). Our molecular results support this view.

Two subspecies of $V$. canescens, subsp. canescens and subsp. pedunculata, differing from each other by the length of their peduncle (Browicz 1978), are closely related taxa in some anatomical and palynological aspects (Güven 2017). Our analyses showed that these two subspecies had identical chromosome numbers of $2 n=22$ (diploid), and had identical sequences. Further molecular studies involving more gene regions will be needed to resolve the identity of the two subspecies.

Vincetoxicum fuscatum was represented by two morphologically close subspecies, subsp. boissieri and subsp. fuscatum, distinguished only by the corolla indumentum in the Flora of Turkey (Browicz 1975). Our analyses show that the two subspecies are tetraploid. While this was the first chromosome count for the subsp. boissieri, the chromosome number of $2 n=22$ (diploid) has been reported for the subsp. fuscatum from Greece (Strid \& Franzen 1981). The intraspecific differentiation of the ploidy level within the plant species might be a result of the geographical distribution of the taxa (Morawetz 1984). In support of this, it has been reported that plant taxa collected from various geographical regions can have different chromosome numbers (Ozcan et al. 2008). Similarly, the chromosome number of $V$. nigrum from Spain has been reported as $2 n=2 x=22$ (diploid) (Aparicio \& Silvestre 1985), whereas it was counted as $2 n=4 x=44$ (tetraploid) in populations distributed in both the Netherlands (Van den Brand et al. 1979) and Canada (Liede-Schumann et al. 2012). These differences can be caused by the variations in populations of $V$. nigrum and in environmental conditions between different geographical regions.

The taxa of $V$. fuscatum clustered under the same subclade together with $V$. maeoticum from Russia and $V$. intermedium from Kazakhstan (Fig. 3), corresponding to the 'Southern Russian clade' of LiedeSchumann et al. (2016). Marhold (2011) reported that $V$. maeoticum and $V$. intermedium are probably synonyms of $V$. fuscatum subsp. fuscatum. This view is supported by our molecular results. Browicz (1978) recognised that V. fuscatum subsp. boissieri and V. fuscatum subsp. fuscatum, which were distinguished only by their corolla indumentum, were separated at the subspecies level based on high morphological similarities. However, Pobedimova (1952) previously treated these two taxa as separate 
species named Antitoxicum boissieri (Kusn.) Pobed. (= V. fuscatum subsp. boissieri) and Antitoxicum minus (K.Koch) Pobed. (=V. fuscatum subsp. fuscatum). Our karyological analyses showed that these two subspecies of $V$. fuscatum had identical chromosome numbers of $2 n=44$ (tetraploid). Otherwise, in our molecular analyses, three specimens of subsp. boissieri formed a well-supported subclade among the unresolved specimens of $V$. fuscatum subsp. fuscatum, $V$. maeoticum and $V$. intermedium. We therefore suggest to raise $V$. fuscatum subsp. boissieri to the species level sister to V. fuscatum according to the present molecular data.

The somatic chromosome number of $V$. hirundinaria subsp. hirundinaria, which was the first report from Turkish accessions, was determined as $2 n=2 x=22$. Our results are consistent with the previous counts reported by Uhríková et al. (1985) in Slovakia and Liede-Schumann et al. (2012) in Germany. The present study revealed a diploid chromosome number of $2 n=2 x=22$ for $V$. scandens and $V$. speciosum from Turkish accessions. These findings are in agreement with the previous results of $V$. scandens in Iran (Lessani \& Chariat-Panahi 1979) and V. speciosum in Italy (Pardi 1933). In this study, the chromosome number of $V$. funebre was determined for the first time as $2 n=2 x=22$ from a Turkish accession.

Vincetoxicum hirundinaria subsp. hirundinaria, characterised by white-flowers, clustered with V.jailicola, V. rossicum and V. schmalhausenii (the European clade, according to Liede-Schumann et al. 2016), forming a clade in sister-group position to $V$. funebre, $V$. rehmannii and $V$. scandens (the Irano-Turanian clade according to Liede-Schumann et al. 2016), as well as to $V$. speciosum. The present molecular results are in accordance with the chromosome counts as well as some morphological and palynological features of individuals of the four Turkish Vincetoxicum taxa (V. funebre, V. hirundinaria subsp. hirundinaria, V. scandens and V. speciosum). Güven (2017) also reported that these taxa were characterised by a densely or sparsely hairy corolla with cup-shaped corona and obovate pollinia.

Vincetoxicum scandens, characterised by twining stems up to $2 \mathrm{~m}$ high, clustered with $V$. funebre, which is known to have erect and shorter $(40-135 \mathrm{~cm})$ stems. However, these taxa have some floral features in common, such as hairy corolla and cup-shaped five-parted corona (Pobedimova 1952; Güven 2017). Furthermore, V.funebre and $V$. scandens have similar palynological (obovate pollinium and oblong corpusculum) characteristics (Güven et al. 2015) and the same chromosome number of $2 n=2 x=22$.

Vincetoxicum speciosum accessions formed a distinct subclade. In Turkey, V. hirundinaria subsp. hirundinaria and V.speciosum share the same overlapping humid habitats such as Quercus-forest openings in northwest Anatolia and Thrace regions. However, these two diploid representatives of Vincetoxicum can easily be differentiated by their morphological and palynological characteristics. While $V$. speciosum is characterised by a blackish purple corolla and an erect stem with wholly velutinous pubescence, $V$. hirundinaria subsp. hirundinaria has a white corolla and crisped hairy stems that occasionally twine near the apex (Browicz 1975). Güven et al. (2015) noted that the pollinia surface of $V$. speciosum exhibited gemmate ornamentation, in contrast to the rugulate surface in $V$. hirundinaria subsp. hirundinaria. Furthermore, V. speciosum was characterised by the longest obovate pollinium among the Turkish Vincetoxicum s. str. taxa (Güven et al. 2015).

Vincetoxicum nigrum is characterised by a weak twining stem and dark blackish-purple coloured and hairy flowers. Browicz (1978) indicated that the records previously reported from Anatolia for V. nigrum were incorrect and so they were treated under $V$. scandens. Vincetoxicum nigrum is morphologically similar to $V$. scandens but differs from this species by its weak growth, smaller leaves, shorter peduncles (not more than $1 \mathrm{~cm}$ ), and cup-shaped corona with small coronal teeth (Markgraf 1972; Browicz 1978). Additionally, while both di- $(2 n=22)$ and tetraploid $(2 n=44)$ chromosome numbers have been counted for V. nigrum (Liede-Schumann et al. 2012), the chromosome counts for $V$. scandens, reported in both 
the present and previous (Lessani \& Chariat-Panahi 1979) studies, were all $2 n=22$ (diploid). These two species are also located in different subclades according to the present molecular results.

In the present study, the chromosome number of $V$. parviflorum was determined for the first time as $2 n=2 x=22$ from a Turkish accession. In the Flora of Turkey, Browicz (1978) reported that V. parviflorum could be a small-flowered variety of $V$. fuscatum due to their similar flowers and habits. However, Boissier (1875), who treated V. fuscatum and V. parviflorum as different at the species level, noted that these two taxa differ from each other in a number of morphological characters related to the stem and the flower. In accordance with Boissier (1875), Güven et al. (2015) also determined that although $V$. parviflorum exhibited an elliptic pollinium, two subspecies of $V$. fuscatum were characterised by a clavate pollinium. While the somatic chromosome number was determined as $2 n=22$ (diploid) in $V$. parviflorum, it was counted as $2 n=44$ (tetraploid) for both subspecies of $V$. fuscatum. Our molecular analysis also showed that $V$. parviflorum separated from taxa of $V$. fuscatum and clustered in a different subclade with V. assadii, V. mozaffarianii and V. pumilum (Eastern Irano-Turanian taxa according to Liede-Schumann et al. (2016)).

In conclusion, the results of our phylogenetic analyses, including 31 newly generated ITS and trnT$\operatorname{tr} \mathrm{L}$ sequences belonging to 10 taxa of Vincetoxicum s. str. from Turkey, agrees largely with previous phylogenetic results (Liede-Schumann et al. 2016). In addition to the previous study, DNA sequences were determined for V. fuscatum subsp. boissieri and V. parviflorum endemic to Turkey, as well as $V$. speciosum of European origin. Of the studied taxa, V. fuscatum, V. parviflorum and V. speciosum are clearly resolved at the species level, whereas the delimitation of the rest of the Turkish taxa was less clear based on molecular data. Three specimens of the endemic V. fuscatum subsp. boissieri formed a wellsupported subclade within the clade including unresolved specimens of V. fuscatum subsp. fuscatum, $V$. maeoticum and $V$. intermedium. We therefore suggest that $V$. fuscatum subsp. boissieri, previously treated as Antitoxicum boissieri by Pobedimova (1952), should be raised to the species level, sister to $V$. fuscatum. The other endemic taxon V. parviflorum, reported as a morphologically related taxon to V. fuscatum by Browicz (1978), separated from the V. fuscatum taxa and clustered in a different clade, sister to V. assadii, V. mozaffarianii and V. pumilum from Iran. The molecular results were evaluated together with some typical floral characteristics of Vincetoxicum s. str., such as the indumentum of the corolla and shape of the corona (which were not analysed). Nevertheless, these characters seemed to be homoplastic, since they appeared in different subclades.

\section{Acknowledgement}

The authors extend their thanks to Recep Tayyip Erdogan University Scientific Research Projects Coordination Unit (Project number 2015.53007.102.03.06) for the financial support.

\section{References}

Ali S.I. 1983. Asclepiadaceae. In: Nasir E. \& Ali S.I. (eds) Flora of Pakistan-Karachi. Vol. 150: 1-165. University of Karachi Press, Pakistan.

Altundağ E. \& Öztürk M. 2011. Ethnomedicinal studies on the plant resources of east Anatolia, Turkey. Procedia Social and Behavioral Sciences 19: 756-777. https://doi.org/10.1016/j.sbspro.2011.05.195

Aparicio A. \& Silvestre S. 1985. Números cromosómicos para la flora Española. Lagascalia 13 (2): 318-323.

Boissier E.P. 1875. Vincetoxicum Maench. In: Boissier E.P. (ed.) Flora Orientalis: 51-56. H. Georg, Basileae, Genevae. 
Browicz K. 1975. Vincetoxicum canescens (Willd.) Decne. and V. tmoleum Boiss. Systematic problems and geographical distribution. Fragmenta Floristica et Geobotanica 21: 261-271.

Browicz K. 1978. Vincetoxicum Wolf. In: Davis P.H. (ed.) Flora of Turkey and East Aegean Islands. Vol. 7: 167-173. Edinburgh University Press, Edinburgh.

Chang Y.H., Tzeng H.Y. \& Tseng Y.H. 2012. Pollinaria morphology of Cynanchum L. (Asclepiadaceae) in Taiwan. Quarterly Journal of Forestry Research 34 (4): 251-262.

Civeyrel L., Thomas A.L., Ferguson K. \& Chase M.W. 1998. Critical reexamination of palynological characters used to delimit Asclepiadaceae in comparison to the molecular phylogeny obtained from plastid matK sequences. Molecular Phylogenetics and Evolution 9 (3): 517-527.

https://doi.org/10.1006/mpev.1997.0510

DiTommaso A., Lawlor F.M. \& Darbyshire S.J. 2005. The biology of invasive alien plants in Canada, 2, Cynanchum rossicum (Kleopow) Borhidi [=Vincetoxicum rossicum (Kleopow) Barbar.] and Cynanchum louiseae (L.) Kartesz \& Gandhi [= Vincetoxicum nigrum (L.) Moench]. Canadian Journal of Plant Science 85: 243-263.

Doğan A. 2008. Ovacık-Tunceli yöresinin geleneksel halk ilacı olarak kullanılan bitkileri. Master's thesis, Marmara Üniversitesi, Istanbul.

Domin K. 1928. Beiträge zur flora und pflanzengeographie Australiens. Bibliotheca Botanica 22 (89): $1033-1128$.

Doyle J.J. \& Dolye J.L. 1987. A rapid DNA isolation procedure for small quantities of fresh leaf tissue. Phytochemical Bulletin 19: 11-15.

Ekim T., Koyuncu M., Vural M., Duman H., Aytaç Z. \& Adıgüzel N. 2000. Türkiye Bitkileri Kırmızı Kitabı (Ĕgrelti ve Tohumlu Bitkiler). Doğal Hayatı Koruma Derneği, Ankara.

Elçi Ş. 1994. Sitogenetikte araştırma yöntemleri ve gözlemler. 100. Y11 Üniversitesi Yayınları, Van.

Feng Y., Qin X., Huang J. \& Hong W. 2012. Pollinarium morphology of 17 species and 1 subspecies of Cynanchum (Asclepiadaceae). Acta Botanica Boreali-Occidentalia Sinica 32 (9): 1758-1762.

Forster P.I. 1991. A taxonomic revision of Cynanchum L. (Asclepiadaceae: Asclepiadoideae) in Australia. Austrobaileya 3: 443-466.

Garbari F., Bedini G. \& Peruzzi L. 2012. Chromosome numbers of the Italian flora. From the Caryologia foundation to present. Caryologia 65 (1): 62-71. https://doi.org/10.1080/00087114.2012.678090

Gaynor M.L., Ng J. \& Laport L.G. 2018. Phylogenetic structure of plant communities: Are polyploids distantly related to co-occurring diploids? Frontiers in Ecology and Evolution 6: 52.

https://doi.org/10.3389/fevo.2018.00052

Goyder D., Nicholas A. \& Liede-Schumann S. 2007. Phylogenetic relationships in subtribe Asclepiadinae (Apocynaceae:Asclepiadoideae). Annals of the Missouri Botanical Garden 94: 423-434.

https://doi.org/10.3417/0026-6493(2007)94[423:PRISAA]2.0.CO;2

Gregg W.C.T., Ather S.H. \& Hahn M.W. 2017. Gene-Tree reconciliation with MUL-Trees to resolve polyploidy events. Systematic Biology 66 (6): 1007-1018. https://doi.org/10.1093/sysbio/syx044

Grossheim A.A. 1967. Flora of the Caucasus. 7. Academy of Sciences Press, Moscow/Leningrad.

Gültepe M., Uzuner U., Coşkunçelebi K., Beldüz A.O. \& Terzioğlu S. 2010. Internal transcribed spacer (ITS) polymorphism in the wild Primula (Primulaceae) taxa of Turkey. Turkish Journal of Botany 34: 147-157. https://doi.org/10.3906/bot-0905-23 
Güner A. 2012. Vincetoxicum Wolf. In: Güner A., Aslan S., Ekim T., Vural M. \& Babaç M.T. (eds) Türkiye bitkileri listesi (Damarlı bitkiler): 85-86. Nezahat Gökyiğit Botanik Bahçesi ve Flora Araştırmaları Derneği Yayını.

Güven S. 2017. Türkiye Vincetoxicum (Apocynaceae Asclepiadoideae) cinsinin taksonomik revizyonu. PhD Thesis, Recep Tayyip Erdoğan Üniversitesi, Rize.

Güven S., Makbul S., Coskuncelebi K. \& Pinar N.M. 2015. Pollinarium morphology of the genus Vincetoxicum Wolf (Apocynaceae: Asclepiadoideae) in Turkey. Phytotaxa 230 (1): 22-38.

https://doi.org/10.11646/phytotaxa.230.1.2

Hall T.A. 1999. BioEdit: A user-friendly biological sequence alignment editor and analysis program for windows 95/98/NT. Nucleic Acids Research 41: 95-98.

İlçim A., Özay S.G. \& Kökdil G. 2010. Exomorphic seed characters and anatomy of leaf and stem of some Vincetoxicum (Asclepiadaceae/Apocynaceae) species from Turkey. Journal of Faculty of Pharmacy of Ankara University 39 (1): 1-16. https://doi.org/10.1501/Eczfak_0000000550

Jones R.N. \& Rickards G.K. 1991. Practical genetics. Open University Press, Philadelphia.

Kumar S., Stecher G. \& Tamura K. 2016. MEGA7: Molecular Evolutionary Genetics Analysis version 7.0 for bigger datasets. Molecular Biology and Evolution 33 (7): 1870-1874.

https://doi.org/10.1093/molbev/msw054

Lahaye R., Civeyrel L., Speck T. \& Rowe N.P. 2005. Evolution of shrub-like growth forms in the lianoid subfamily Secamonoideae (Apocynaceae s.1.) of Madagascar: phylogeny, biomechanics, and development. American Journal of Botany 92 (8): 1381-1396. https://doi.org/10.3732/ajb.92.8.1381

Leliaert F., Verbruggen H., Vanormelingen P., Steen F., López-Bautista J.M., Zuccarello G.C. \& De Clerck O. 2014. DNA-based species delimitation in algae. European Journal of Phycology 49: 179-196. https://doi.org/10.1080/09670262.2014.904524

Lessani H. \& Chariat-Panahi S. 1979. In: Löve A. (ed.) IOPB chromosome number reports LXV: 635636. Taxon 28 (4): 627-637.

Li P.T., Gilbert M.G. \& Stevens W.D. 1995. Asclepiadaceae. In: Wu Z.Y. \& Raven P.H. (eds) Flora of China. Vol. 16: 189-270. Missouri Botanical Garden Press, St. Louis.

Liede S. 1996. Cynanchum-Rhodostegiella-Vincetoxicum-Tylophora (Asclepiadaceae): new considerations on an old problem. Taxon 45: 193-211. https://doi.org/10.2307/1224660

Liede S. 2001. Subtribe Astephaninae (Apocynaceae-Asclepiadoideae) reconsidered: new evidence based on cpDNA spacers. Annals of the Missouri Botanical Garden 88 (4): 657-668.

https://doi.org/10.2307/3298638

Liede S. \& Täuber A. 2002. Circumscription of the genus Cynanchum (Apocynaceae-Asclepiadoideae). Systematic Botany 27(4): 789-800.

Liede S., Täuber A. \& Schneidt J. 2002. Molecular considerations in the Tylophorinae K.Schum. (Apocynaceae-Asclepiadoideae). Edinburgh Journal of Botany 59 (3): 377-403.

https://doi.org/10.1017/S0960428602000239

Liede-Schumann S. \& Meve U. 2018. Vincetoxicum (Apocynaceae-Asclepiadoideae) expanded to include Tylophora and allies. Phytotaxa 369 (3): 129-184. https://doi.org/10.11646/phytotaxa.369.3.1

Liede-Schumann S., Kong H., Meve U. \& Thiv M. 2012. Vincetoxicum and Tylophora (Apocynaceae:Asclepiadoideae:Asclepiadeae) - two sides of the same medal: independent shifts from tropical to temperate habitats. Taxon 61 (4): 803-825. https://doi.org/10.1002/tax.614007 
Liede-Schumann S., Khanum R., Mumtaz A.S., Gherghel I. \& Pahlevani A. 2016. Going west - a subtropical lineage (Vincetoxicum, Apocynaceae: Asclepiadoideae) expanding into Europe. Molecular Phylogenetics and Evolution 94: 436-446. https://doi.org/10.1016/j.ympev.2015.09.021

Mansoor A., Ibrahim M.A., Zaidi M.A. \& Ahmed M. 2011. Antiprotozoal activities of Vincetoxicum stocksii and Carum copticum. Bangladesh Journal of Pharmacology 6: 51-54.

https://doi.org/10.3329/bjp.v6i1.8442

Marhold K. 2011. Apocynaceae. In: Euro+Med Plantbase - the information resource for EuroMediterranean plant diversity. Available from http://ww2.bgbm.org/EuroPlusMed [accessed 6 Nov. 2018].

Markgraf F. 1972. Vincetoxicum Wolf. In: Tutin T.G. et al. (eds) Flora Europaea. Vol. 3: 71-73. Cambridge University Press, Cambridge.

Martin E., Doğan G.İ., Erkul S.K. \& Eroğlu H.E. 2019. Karyotype analyses of 25 Turkish taxa of Astragalus from the sections Macrophyllium, Hymenostegis, Hymenocoleus, and Anthylloidei (Fabaceae). Turkish Journal of Botany 43 (2): 232-242. https://dergipark.org.tr/tr/pub/tbtkbotany/issue/45555/572487

Morawetz W. 1984. Karyological races and ecology of the Brazilian Duguetia furfuracea as compared with Xylopia aromatica (Annonaceae). Flora 175: 195-209.

Müller K. 2004. PRAP - computation of Bremer support for large datasets. Molecular Phylogenetics and Evolution 31: 780-782. https://doi.org/10.1016/j.ympev.2003.12.006

Müller K. 2005. SeqState: Primer design and sequence statistics for phylogenetic DNA datasets. Applied Bioinformatics 4 (1): 65-69.

Nixon K.C. 1999. The parsimony ratchet, a new method for rapid parsimony analysis. Cladistics 15: 407-414. https://doi.org/10.1006/clad.1999.0121

Nylander J.A.A. 2004. MrModeltest v2. Evolutionary Biology Centre, Uppsala University, Uppsala [program distributed by the author].

Özay S.G. 2013. Bazı Vincetoxicum N.M. Wolf (Asclepiadaceae) türleri üzerinde farmakognozik araştırmalar. $\mathrm{PhD}$ thesis, Mersin Üniversitesi, Mersin.

Ozcan M., Ayaz S.H. \& İnceer H. 2008. Chromosome counts of some Cirsium (Asteraceae, Cardueae) taxa from Turkey. Caryologia 61 (4): 375-382. https://doi.org/10.1080/00087114.2008.10589649

Pardi P. 1933. Studi sulla cariologia delle Asclepiadaceae. Nuovo Giornale Botanico Italiano 40(4): 576-589.

Pobedimova G. 1952. Antitoxicum. In: Shishkin B.K. \& Bobrov E.G. (eds) Flora of USSR. Vol. 18: 674-691. Academy of Science of the USSR Press, Leningrad/Moscow.

Rechinger K.H. 1970. Flora Iranica. Vol. 73. Akademische Druck \& Verlagsanstalt, Graz.

Rice A., Glick L., Abadi S., Einhorn M., Kopelman N.M., Salman-Minkov A., Mayzel J., Chay O. \& May I. 2015. The chromosome counts database (CCDB) - a community resource of plant chromosome numbers. New Phytologist 206 (1): 19-26. https://doi.org/10.1111/nph.13191

Ronquist F. \& Huelsenbeck J.P. 2003. MrBayes version 3.0: bayesian phylogenetic inference under mixed models. Bioinformatics 19 (12): 1572-1574. https://doi.org/10.1093/bioinformatics/btg180

Sennblad B. 1997. Phylogeny of the Apocynaceae s.l. PhD thesis, Acta Universitas Uppsaliensis, Uppsala. 
Shah S.A. \& Ahmad M. 2014. Reassessing palynological characters in the subfamilies Periplocoideae and Asclepiadoideae (Apocynaceae): taxonomic and evolutionary implications. Palynology 38 (2): 224-234. https://doi.org/10.1080/01916122.2014.893264

Simmons M.P. \& Ochoterena H. 2000. Gaps as characters in sequence-based phylogenetic analyses. Systematic Biology 49: 369-381. https://doi.org/10.1093/sysbio/49.2.369

Stace C.A. 2000. Cytology and cytogenetics as a fundamental taxonomic resource for the $20^{\text {th }}$ and $21^{\text {st }}$ centuries. Taxon 49 (3): 451-477. https://doi.org/10.2307/1224344

Stærk D., Lykkeberg A.K., Christensen J., Budnik B.A., Abe F. \& Jaroszewski J.W. 2002. In vitro cytotoxic activity of phenantroindolizidine alkaloids from Cynanchum vincetoxicum and Tylophora tanakae against drug-sensitive and multidrug-resistant cancer cells. Journal of Natural Products 65 (9): 1299-1302. https://doi.org/10.1021/np0106384

Strid A. \& Franzen R. 1981. In: Löve A. (ed.) Chromosome number reports LXXIII: 829-842. Taxon 30 (4): 829-861.

Swofford D.L. 2003. PAUP - phylogenetic analysis using parsimony version 4. Sinauer Associates, Sunderland (Massachusetts).

Taberlet P., Gielly L., Pautou G. \& Bouvet J. 1991. Universal primers for amplification of three noncoding regions of chloroplast DNA. Plant Molecular Biology 17: 1105-1109.

Tsiang Y. \& Li P.T. 1977. Asclepiadaceae. In: Tsiang Y. \& Li P. (eds) Flora Reiplicae Popularis Sinicae. Vol. 63: 249-575. Science Press, Beijing.

Uhríková A., Feráková V. \& Schwarzová T. 1985. Karyologisches studium der Slowakischen Flora VI. Acta Facultatis Rerum Naturalium Universitatis Comenianae-Botanica 32: 57-70.

Van den Brand C., Van Meel F.C.M. \& Wieffering J.H. 1979. In: Löve A. (ed.) IOBP chromosome number reports LXIV: 395-397. Taxon 28 (4): 391-408.

Vladimirov V., Coşkunçelebi K. \& Tan K. 2015. A new diploid species of Pilosella Asteraceae) from Turkey. Turkish Journal of Botany 39: 70-75. https://doi.org/10.3906/bot-1401-92

White T.J., Bruns T., Lee S. \& Taylor J. 1990. Amplification and direct sequencing of fungal ribosomal DNA for phylogenetics. In: Innis M.A., Gelfand D.H., Sninsky J.J. \& White.T. J. (eds.) PCR Protocols: a Guide to Methods and Applications: 315-321. Academic Press, San Diego (CA).

Woodland D.W. 1997. Contemporary Plant Systematics. Andrews University Press, Berrien Springs (MI).

Yamashiro T., Fukuda T., Yokoyama J. \& Maki M. 2004. Molecular phylogeny of Vincetoxicum (Apocynaceae-Asclepiadoideae) based on the nucleotide sequences of cpDNA and nrDNA. Molecular Phylogenetics and Evolution 31 (2): 689-700. https://doi.org/10.1016/j.ympev.2003.08.016

Yamashiro T., Yamashiro A., Yokoyama J. \& Maki M. 2008. Morphological aspects and phylogenetic analyses of pollination systems in the Tylophora-Vincetoxicum complex (Apocynaceae-Asclepiadoideae) in Japan. Biological Journal of the Linnean Society 93: 325-341.

https://doi.org/10.1111/j.1095-8312.2007.00896.x

Yaseen S. \& Perveen A. 2014. Pollinia morphology to some members of Asclepiadaceae of Pakistan. Bangladesh Journal of Botany 43 (3): 249-253.

Zaidi M.A. \& Crow Jr S.A. 2005. Biologically active traditional medicinal herbs from Balochistan, Pakistan. Journal of Ethnopharmacology 96: 331-334. 
Zaidi M.A. \& Crow Jr S.A. 2012. Cytotxicity of four medicinal plants of Pakistan. Pakistan Journal of Botany 44: 395-397.

Manuscript received: 28 March 2019

Manuscript accepted: 26 September 2019

Published on: 31 December 2019

Topic editor: Frederik Leliaert

Desk editor: Connie Baak

Printed versions of all papers are also deposited in the libraries of the institutes that are members of the EJT consortium: Muséum national d'histoire naturelle, Paris, France; Meise Botanic Garden, Belgium; Royal Museum for Central Africa, Tervuren, Belgium; Royal Belgian Institute of Natural Sciences, Brussels, Belgium; Natural History Museum of Denmark, Copenhagen, Denmark; Naturalis Biodiversity Center, Leiden, the Netherlands; Museo Nacional de Ciencias Naturales-CSIC, Madrid, Spain; Real Jardín Botánico de Madrid CSIC, Spain; Zoological Research Museum Alexander Koenig, Bonn, Germany; National Museum, Prague, Czech Republic. 
GÜVEN S. et al., Vincetoxicum of Turkey

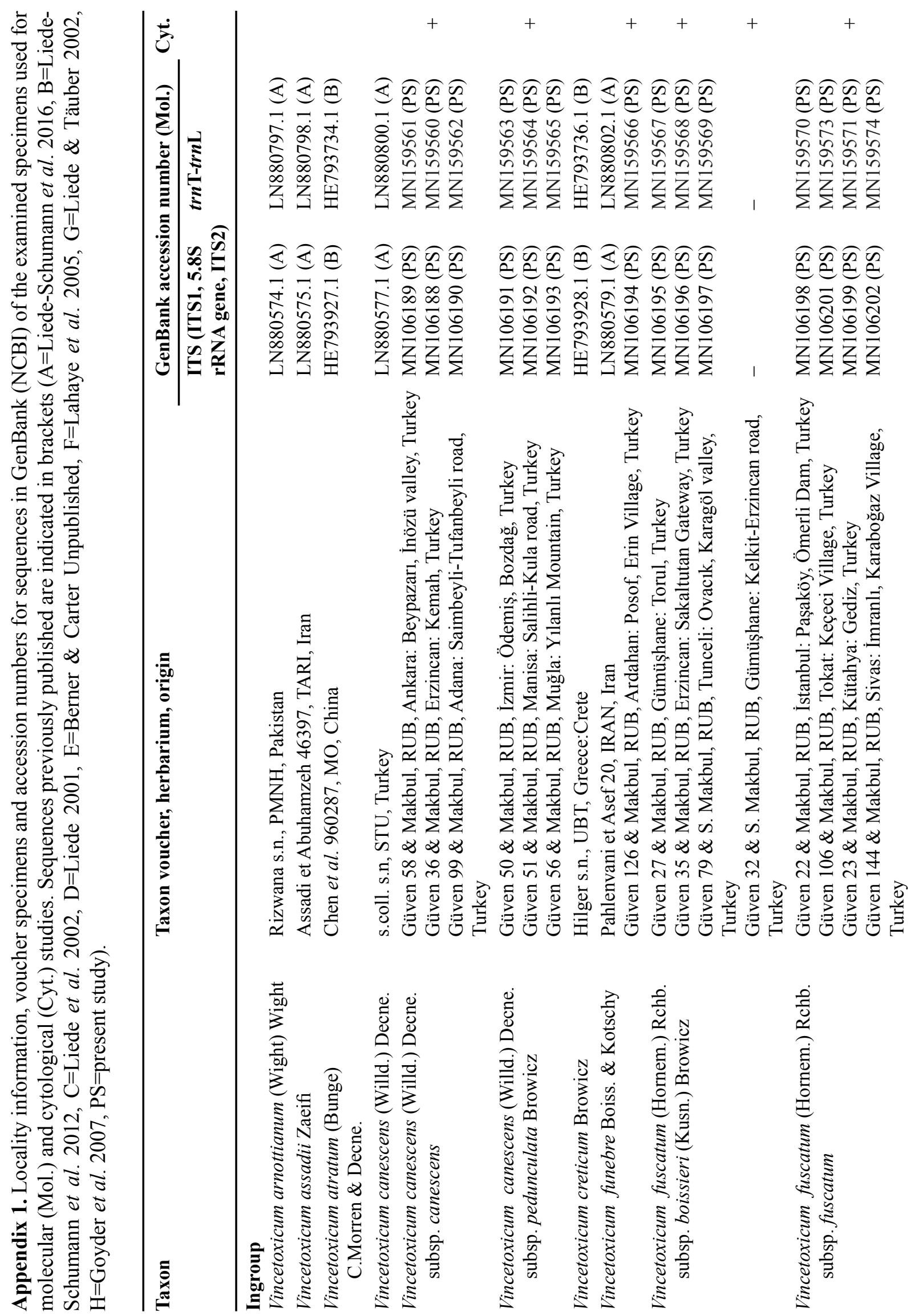




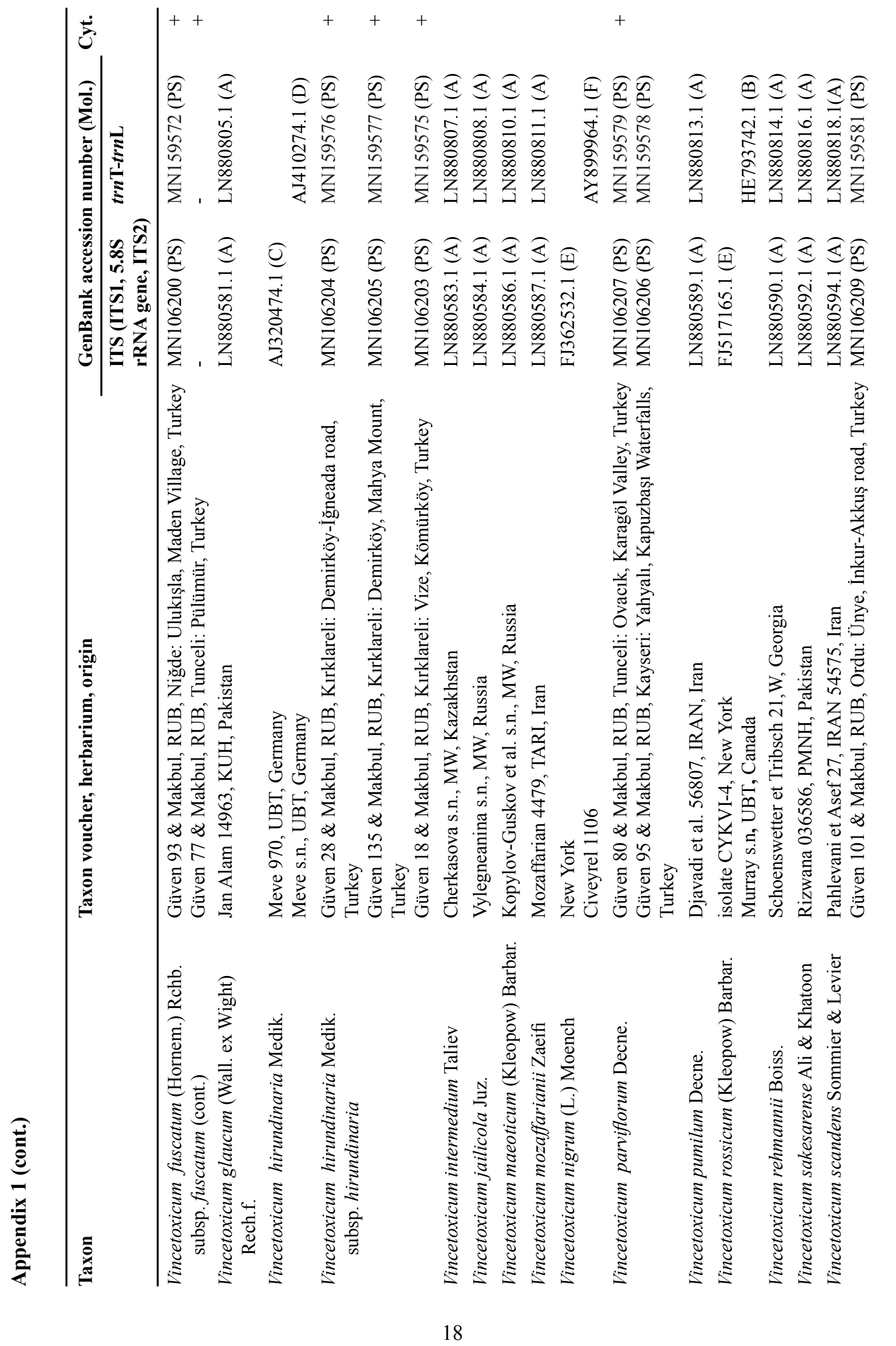




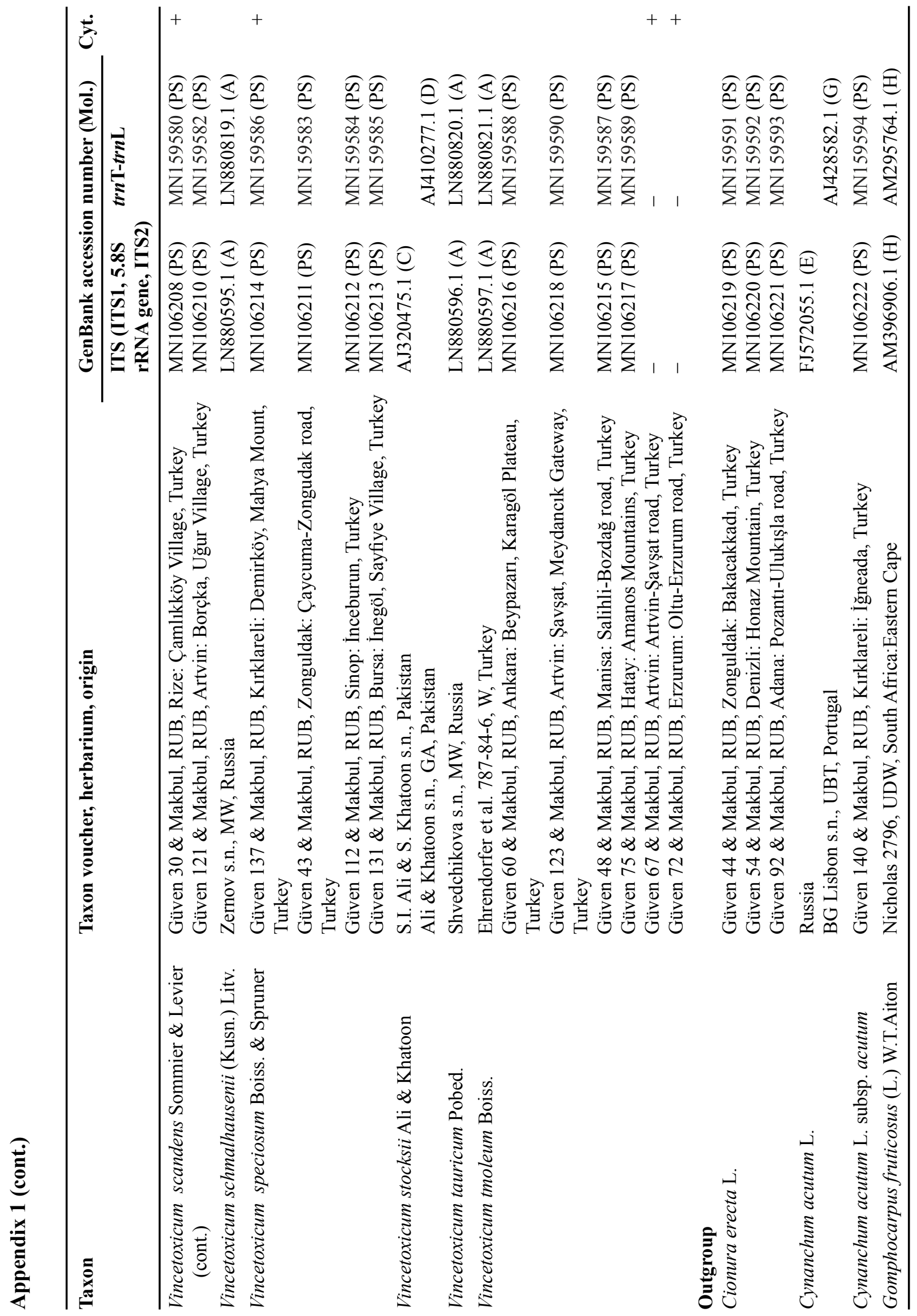

